\title{
Protective effect of rocket leaves against DNA damage is species specific and not affected by light intensity during cultivation
}

\author{
Jing Jin ${ }^{1}$, Olga Koroleva ${ }^{2}$, June Swanston ${ }^{1}$, Jane Magan ${ }^{1}$, Carol Wagstaff ${ }^{1}$ and Ian Rowland ${ }^{1}$ \\ ${ }^{1}$ Department of Food Bioscience, University of Reading, Reading, UK and ${ }^{2}$ Biocentre, University of Reading, Reading, UK
}

Consumption of Brassicaceae vegetables, which contain a wide range of health-promoting phytochemicals including glucosinolates, vitamins and flavonoids, is associated with reduced risk of many types of cancer ${ }^{(1)}$. Eruca sativa cv. Sky (also termed salad rocket) and Diplotaxis tenuifolia cv. Voyager (wild rocket) are Brassicaceae and their leaves are increasingly eaten alone or as part of salads and soups. The quantities of glucosinolates were compared using liquid chromatography-MS and those of flavonoids using HPLC in Sky and Voyager rocket leaves from plants exposed to high $\left(80-120 \mu \mathrm{mol} / \mathrm{m}^{2}\right.$ per s) or low $\left(20-30 \mu \mathrm{mol} / \mathrm{m}^{2}\right.$ per s) light intensities for 6 weeks. The ability of leaf extracts (freeze-dried leaves extracted in $700 \mathrm{ml}$ methanol/l water or $2 \mathrm{M}-\mathrm{HCl}$ in methanol) to protect colon cells from DNA damage was assessed using the Comet assay ${ }^{(2)}$. Total glucosinolate concentration and contents of flavonoids, including quercetin, kaempferol and isorhamnetin, in both cultivars of rocket responded significantly to light $(P<0.05)$. Voyager rocket leaves contained a similar amount of 4-mercaptobutyl-glycosinolate (the major glucosinolate in rocket species), regardless of the light intensity. Under low light the amount of flavonoids in the leaf of Sky and Voyager rocket was the same, except that there was more quercetin in Voyager rocket leaf. In contrast, Voyager rocket leaf exposed to high light intensity contained more quercetin and isorhamnetin and less kaempferol. Interestingly, only glucosinolate extracts from Sky rocket leaves showed a significant protective effect against $\mathrm{H}_{2} \mathrm{O}_{2}$ induced DNA damage in human colon cancer HT-29 cells (Figure). High or low light intensity during plant cultivation did not influence the effect of rocket extracts on DNA damage. The addition of myrosinase, the enzyme hydrolyzing glucosinolates into isothiocyanates, had no obvious effect on the protective ability of glucosinolates extracts of both species of rocket leaves. In summary, rocket leaves were species-specific for their protective effect against oxidative DNA damage, but high light intensity, although dramatically increasing the content of phytochemicals in rocket leaves, was not associated with increased protective potential. The present study indicates that consumption of Sky rocket might be linked to a reduced risk of cancer via decreased damage to DNA.

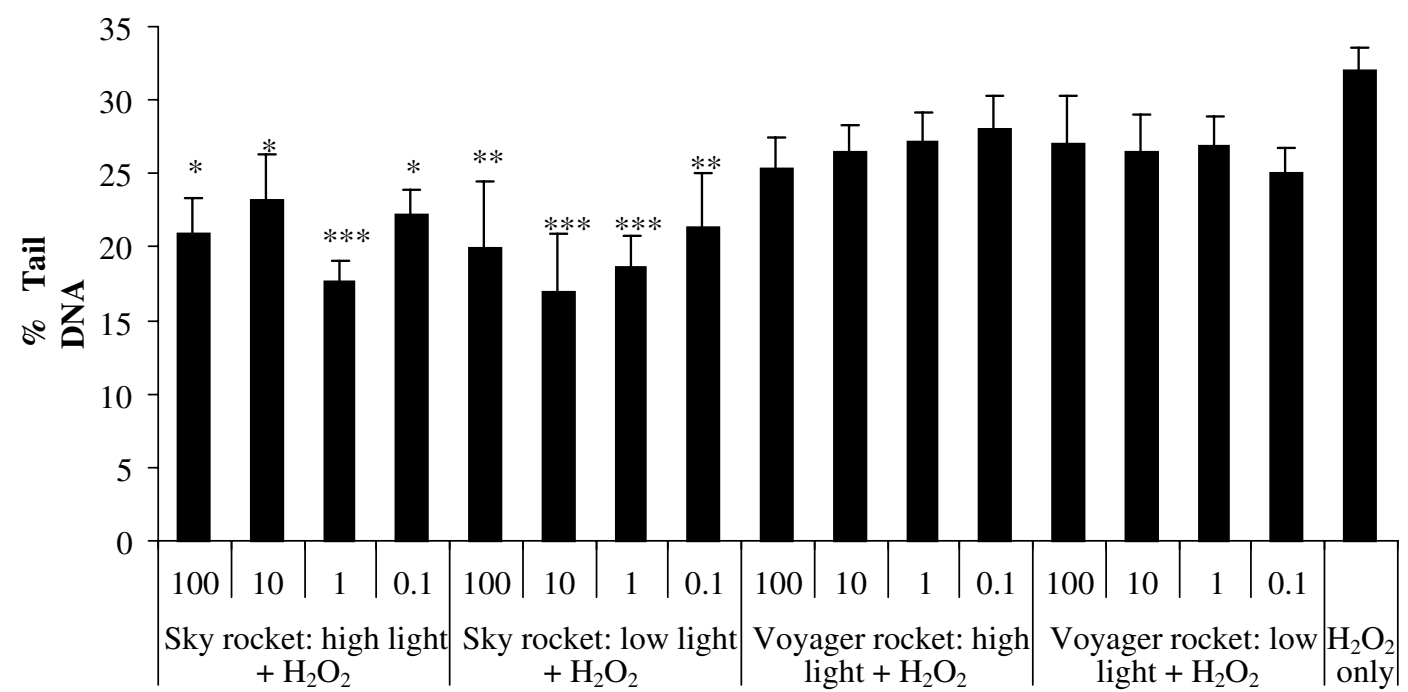

Figure. Protective effect of rocket leaf extracts $\left(\mu \mathrm{g}\right.$ dry wt/ml) rich in glucosinolates against $75 \mu_{\mathrm{M}}-\mathrm{H}_{2} \mathrm{O}_{2}$-induced DNA damage in HT-29 cells. The cells were treated with extracts for $24 \mathrm{~h}$ before the exposure to $\mathrm{H}_{2} \mathrm{O}_{2}$. Values are means with their standard errors for three rocket plants. Mean values were significantly different from those for $\mathrm{H}_{2} \mathrm{O}_{2}$ only: $* P<0.05, * * P<0.01, * * * P<0.001$.

1. Holst B \& Williamson G (2004) Nat Prod Rep 21, 425-427.

2. McCann MJ, Gill CI, O’Brien G, Rao JR, McRoberts WC, Hughes P, McEntee R \& Rowland IR (2007) Food Chem Toxicol 45, 1224-1230. 